Socialist Studies / Études socialistes 8 (1) Winter 2012

Copyright ๑ 2012 The Author(s)

Article

\title{
G.A. COHEN AND THE ETHICAL CORE OF SOCIALISM: EQUALITY OR LIFE-SUFFICIENCY?
}

\author{
JEFF NOONAN \\ Department of Philosophy, University of Windsor. Windsor, Canada. ${ }^{1}$
}

\begin{abstract}
In this paper I will critically examine G.A.'s Cohen understanding of equality as the normative foundation of socialism. Cohen consistently maintained that inequality was the primary social problem systematically generated by capitalism, and that equality was the primary normative foundation of the socialist alternative. The general question that I want to pose in this paper is: is Cohen's understanding of equality as the normative foundation of socialism consistent with his general conception of socialism as a systemic alternative to capitalism? I will answer that it is not, because equality is not the best normative foundation for socialism conceived of as a systematic alternative to capitalism, and that elements of Cohen's own work imply a deeper normative foundation in what I call the principle of life-sufficiency.
\end{abstract}

\section{Résumé}

Cet article examine la façon dont G.A. Cohen comprenait l'égalité comme l'un des fondements normatifs du socialisme. Cohen a argumenté que l'inégalité est le premier problème social du capitalisme, et que l'égalité est le premier fondement normatif de l'alternative socialiste. Dans cet article, je m'interroge sur la cohérence entre l'idée portée par Cohen selon laquelle l'égalité est le fondement normatif du socialisme et sa conception générale du

\footnotetext{
${ }^{1}$ Jeff Noonan is Professor and Head of the Department of Philosophy at the University of Windsor. He is the author of Critical Humanism and the Politics of Difference (2003), Democratic Society and Human Needs (2006), and Materialist Ethics and Life-Value (2012, forthcoming). He has also published widely in journals such as Res Publica, Philosophy and Social Criticism, Philosophy Today, Socialist Studies, Re-Thinking Marxism and Dialogue. He may be reached at: Department of Philosophy, University of Windsor, 401 Sunset Avenue, Windsor, Ontario, N9B 3P4. Email: jnoonan@uwindsor.ca.

Jeff Noonan est professeur et directeur du département de philosophie à l'University of Windsor. Il est l'auteur de Critical Humanism and the Politics of Difference (2003), Democratic Society and Human Needs (2006), et Materialist Ethics and Life-Value (2012, forthcoming). Il a également publié abondamment dans des revues telles que Res Publica, Philosophy and Social Criticism, Philosophy Today, Socialist Studies, ReThinking Marxism et Dialogue. Il peut être joint à: Department of Philosophy, University of Windsor, 401 Sunset Avenue, Windsor, Ontario, N9B 3P4. Courriel: jnoonan@uwindsor.ca.
}

Socialist Studies / Études socialistes:

The Journal of the Society for Socialist Studies / Revue de la Société d'études socialistes.

www.socialiststudies.com. ISSN 1918-2821 
socialisme comme une alternative systémique au capitalisme. Je répondrai à cette question par la négative, dans la mesure où l'égalité n'est pas le meilleur fondement d'un socialisme qui cherche à constituer une alternative systémique au capitalisme, et où certains éléments du travail de Cohen suggèrent un fondement plus profond dans ce que j'appelle le principe d' « autosuffisance ».

\section{Keywords}

Cohen; equality; life-sufficiency; Marx; socialism

\section{Mots-clés}

"autosuffisance"; Cohen; égalité; Marx; socialisme,

In Rescuing Justice and Equality G.A. Cohen argued that "what gets socialists going politically" is the question of "why should some people be badly off, when other people are so well off?" (Cohen, 2008, p. 30-1). Cohen notes that this question is not identical to the question of why some people are less well off than others. In that comparative question there is no reference to "absolute levels of condition" (Cohen, 2008, 31). Thus, what motivates socialists, according to Cohen, is the problem of why so many people must exist at or below the absolute minimum conditions of human life.

What they find wrong is that there is, so they think, unnecessary hardship, at the lower end of the scale. There are people who are badly off and who, they believe, would be better off under an equalizing distribution. The practically crucial feature of the situation is that the badly off are worse off than anyone needs to be, since an equalizing redistribution would enhance their lives (Cohen, 2008, 31).

This apparently simple argument raises at least three questions that lead into the heart of the relationship between socialism, liberalism, and egalitarianism central to Cohen's distinguished career in political philosophy. The first is internal to any egalitarian philosophy, socialist or liberal: assuming that people can be made better off by an equalizing distribution, what exactly ought to be equalized. This is the question that initiated the 'equality of what' debate that began in the 1980's with Sen's Tanner Lectures and in which Cohen, along with Ronald Dworkin, and Richard Arneson, was a vigorous participant (Sen, 1980; Dworkin, 1981; Arneson, 1989; Cohen, 1989). The second distinguishes liberal from socialist egalitarians: what are those goods which capitalism cannot distribute equally (thus making socialist egalitarianism necessary)? The third question speaks to a normative debate internal to the history of socialism, in particular the broad Marxist tradition: is the essential problem of capitalism inequality such that the normative basis of socialism is equality? 
In this paper I will primarily be concerned with Cohen's answer to question three. I will have occasion to discuss Cohen's contribution to the equality of what debate, but only in so far as it has implications for his conclusion that equality is the normative foundation of socialism. While there are many norms implicit in the socialist project, I believe that Cohen treats equality as fundamental, and I believe this because, as the quotation above illustrates, he took the struggle against inequality to be the central motivating problem of socialist politics. While Cohen abandoned the revolutionary Marxism of his youth and early career, he never abandoned the deeper Marxist valuecommitment to a world that transcended the selfish egoism and structural inequality of capitalism. He consistently maintained, from his self-critical engagement with the problems of orthodox Marxism in Self-Ownership, Freedom, and Equality to Rescuing Justice and Equality that inequality was the primary social problem systematically generated by capitalism, and that equality was the primary normative foundation of the socialist alternative, however the achievement of that alternative be envisioned. The general question that I want to pose in this paper is: is Cohen's understanding of equality as the normative foundation of socialism consistent with his general conception of socialism as a systemic alternative to capitalism?

I will answer that it is not, because equality is not the best normative foundation for socialism conceived of as a systematic alternative to capitalism, and that elements of Cohen's own work imply a deeper normative foundation. This alternative normative foundation I will call the principle of life-sufficiency. It is the deeper, and thus better, normative foundation in the sense that if it were realized it would solve the sorts of problems that a more equal society would solve, in addition to problems that equality, even of a substantive, socialist sort, would not solve. I will argue that this principle is distinct from principles of distributive equality because principles of distributive equality abstract from differences between people and ignore potential environmental impacts of equalizing consumption at ever higher material levels. As I will demonstrate, the principle of life-sufficiency is implicit but undeveloped in the works of Marx and Engels and also, crucially, Cohen. I will unpack my argument in three steps. In the first, I will explicate what I take to be Marx's and Engels' critique of equality as the normative foundation of socialism and set out their alternative grounding. In the second I will turn to the work of Cohen, spelling out his understanding of equality as the normative foundation of socialism, his reasons for this conclusion, the content of his socialist equality principle, but also what I take to be his alternative grounding. In the concluding section I will demonstrate more precisely how these alternative groundings imply the principle of life-sufficiency and explicate its general social implications.

\section{I: Marx and the Critique of Equality}


While Cohen believed that historical and social changes warranted the repudiation of orthodox, revolutionary Marxism, he remained committed to socialism as a systematic alternative to capitalism. "Any attempt to realize the socialist ideal runs up against entrenched capitalist power and human selfishness. Politically serious people must take those obstacles seriously. But they are not reasons to disparage the ideal itself" (Cohen, 2009, 80). I will examine what Cohen takes this ideal to be, and the essential role that equality plays in it, in the next section. I begin with this point in order to explain the reason why I take Marx's and Engels' critique of equality to be relevant to the evaluation of Cohen's socialist egalitarianism. Cohen does not repudiate that which he takes to be the deepest values of socialism and he never repudiates Marx's and Engels' signal contribution to the explication of those values. Hence, that which Marx and Engels had to say about the relationship between capitalism, socialism, and equality is relevant to the assessment of Cohen's attempt to establish equality as the foundational value of the socialism.

On first examination it appears that there is almost no evidence to support the belief that Marx or Engels believed that equality was a central value, much less the foundational value, of socialist society. Every place one looks - in Marx's early philosophical works, in his political pamphlets, in his systematic political economy, in Engels' elaborations of historical materialism-one finds equality either criticised and dismissed or reduced to a distinct political goal.

One of Marx's first systematic examinations of the relationship between equality and the future alternative society he defended occurs in the Economic and Philosophical Manuscripts of 1844. Marx is abundantly clear that what he means by communism is not equality of wealth or resources or anything else one might care to equalize.

The thought of every piece of private property as such is at least turned against wealthier private property in the form of envy and the urge to reduce things to a common level, so that this envy and urge even constitute the essence of competition. Crude communism is only the culmination of this envy and of this levelling-down (Marx, 1975, 295).

Let us note two claims whose importance is crucial to the argument of the rest of the paper. First, Marx acknowledges that there is some political value to the demand for equality, in so far as it generates opposition to accumulated wealth. Second, this political value is only negative, i..e, it states what communism is against but not what it is for. As we will see, while communism may be against definite forms of inequality, it would be wrong to conclude that the value it is primarily for is equality.

Indeed, even inequality as a negative value motivating opposition to capitalism is ultimately an inadequate motivation, because the ability to recognise inequality does not entail understanding of its systematic causes. For Marx and Engels moral outrage had to 
be combined with understanding of the social causes of the mass poverty that were the object of that outrage. The real cause of inequality, for Marx and Engels, is the class structure of capitalist society. The critique of capitalism thus must ultimately be directed against its class structure, not inequality of wealth or resources. As they argue in the Communist Manifesto, "the immediate aim of the Communists is ... [the] formation of the proletariat into a class, overthrow of the bourgeois supremacy, conquest of political power by the proletariat" (Marx and Engels, 1986, 48). As Engels later elaborated, if "equality" has any meaning as a goal of socialist struggle, it is only in the sense that it is synonymous with the overthrow of class rule. In his polemic with Durhing Engels examines the differing meanings of equality in bourgeois and in proletarian politics.

After admitting that the demand for equality has been a historic demand of both feudal peasant and modern workers, Engels concludes that "the real content of the proletarian demand for equality is the abolition of classes" (Engels, 1959, 147-148). But abolition of classes is not essentially an alternation in the distribution of resources under capitalism, but the end of capitalist social relations and values altogether. Struggles over the distribution of wealth and resources are already central to capitalist society; the struggle for socialism is thus not a struggle for a different distribution of wealth and resources, but a struggle for a different society. The meaning of this distinction can be clarified by turning to a brief examination of Marx's further arguments against equality in Capital and Critique of the Gotha Programme.

It is true that Marx and Engels were willing to employ the idea of equality as a slogan and mobilising tool, but their goal was never to make it the bedrock distributive principle of socialism. They do not make it the bedrock principle of socialism because they tend to regard formal equality as the bedrock principle of capitalist society which creates the legal-political space the proletariat requires to develop its more radically transformative agenda.

The best example of this line of argument is found in Capital, Volume One, where Marx discusses the struggle between capitalists and workers over the duration of the working day:

There is here, therefore, an antinomy, right against right, both equally bearing the seal of the law of exchanges. Between equal right, force decides. Hence it is that in the history of capitalist production, the determination of what is a working day, presents itself as the result of a struggle ... between the class of capitalists ... and the working class (Marx, $1986,225)$.

Equality of rights is not unimportant because, as I noted above, it creates a legal and political space for working class mobilisation. While the immediate goals of these mobilisations might be thought of in terms of creating a more equal material distribution 
(of work time, or whatever other resource might be the particular issue of contention) successful struggles for more equal distributions of resources will not collectively add up to a socialist society. For that to happen, as Marx and Engels made clear, the class structure of capitalism must be abolished.

The structural problem that necessitates the radical transformation of capitalist class structure is not inequality of wealth or resources but rather exclusive class control of the natural and social conditions of life-maintenance and development. It is this structural dependence of human life on capitalist markets that makes the working class dependent and unfree in its life-activity under capitalism. The deepest value underlying socialist society is thus, as Engels put it, "the organization of society in such a way that every member of it can develop and use all of his capabilities and powers in complete freedom and without thereby infringing the basic conditions of this society" (Quoted in Lebowitz, 2006, 13).

This thought, drawn from an early draft of the Communist Manifesto, is more fully developed in Marx's most extended critique of the principle of equality in The Critique of the Gotha Programme. Here Marx's target is the equilsand proposed by the German Social Democratic Party: equality of labour. Equality of labour meant that all labour would be paid at the same rate and only differences due to different quantities of labour supplied would be permitted. Again, Marx accepts, as a matter of historical necessity, that such transitional metrics of socialist distribution might be required, but he is careful to emphasise that to the extent that such abstract metrics must be applied to the distribution of social resources, it is because society is still to that extent rooted in the older capitalist system. "Hence equal right here is still in principle-bourgeois right" (Marx, 1978, 530). Remember that this claim is made in the context of a critique of the idea that equality of labour ought to be the principle of socialist distribution. When we keep this context in mind it is clear that the target of Marx's critique is not, as it might appear, the idea of "bourgeois right" in the abstract, but equal rights as the normative foundation of a socialist system of distribution. He believes that this transitional form is an advance over capitalism in so far as it would attenuate the structural class privileges of capitalism, but he remains critical of the idea of equality, whether construed formally, in relation to rights, or substantively, as the normative foundation of socialist distribution. "Equality" of whatever sort is a problematic normative foundation for socialism because it is an abstraction which masks what is really essential to human life, which is neither the formal rights humans might share in common with others nor how much of something people have in comparison with other people, but what they require as concrete individuals to 'develop their capabilities and powers in complete freedom.'

Marx rejects any metric of equality as the normative foundation of a socialist society because all metrics only function by abstracting from the differences that make people real as individuals. Different individuals, he claims, "are measurable only by an equal standard ... in so far as they are taken from one definite side only" (Marx, 1978, 
530). The truly radical difference between socialism and capitalism is that socialism will secure to each person the natural and social conditions of freely individuating themselves across all dimensions of human experience and activity. Engels makes this point very clearly: "The development of industry will provide society with a quantity of products sufficient to satisfy the needs of all (emphasis added)" (Engels, 1973, 92-93). Achieving this goal requires a principle of distribution governed by the goal of satisfying human needs, not for the sake of ensuring consistency with any abstract metric of equality between people, but rather ensuring sufficiency for each to accomplish their projects. The argument is summed up in Marx's aphorism defining the distributive principle of the fully developed socialist society (communism): "From each according to his abilities, to each according to his needs" (Marx, 1978, 531). There is thus abundant textual evidence to support the claim that Marx and Engels were willing to employ the idea of substantive equality as a mobilizing tool, but also that they consistently regarded the value of equality as more bourgeois than socialist, and not therefore the fundamental value upon which the justification and organization of socialist society would rest.

This textual evidence notwithstanding, the claim that Marx's and Engels' conception of socialism is not fundamentally egalitarian has proven controversial. Alan Wood, for example, reads the textual evidence as I do, concluding that Marx "regards 'equality' as a confusing and outmoded way of representing the goal of abolishing class distinctions ... [and he favours abolishing class distinctions] because he thinks it will lead to other things he values, such as increased human freedom, well-being, community, and individual development or self-actualisation" (Wood, 1981, 212). Yet this reading is rejected by critics like Kai Nielsen, who see no opposition between these goals listed by Wood and constantly asserted by Marx and a certain form of egalitarianism. For Nielsen, the deepest form of egalitarianism affirmed by Marx is what one might call moral egalitarianism and Nielsen calls fairness: "the demand that ...social structures be put in place designed to enhance the lives of everyone where it is taken to as a fundamental guiding principle that the life of each person count and count equally"(Nielsen, 1988, 294). In order to realize this principle, Nielsen goes on to argue, more equal distributions of wealth and resources than are possible under capitalism are necessary: "someone ... who thinks classlessness is important will think social equality is important. Unless we want to attribute a very extensive confusion to Marx and Engels, we cannot say that they valued classlessness and did not value equality as a goal" (Nielsen, 1988, 318).

Cohen, as I will now go on to argue, agrees with the general conclusion arrived at by Nielsen, regarding Marx's critique of capitalism and the distributional principle of fully developed socialist society as egalitarianism. Yet, as the debate between Wood and Nielsen makes clear, there is much normative ambiguity in Marx, ambiguity which is bifurcated between Wood and Nielsen in their debate, but is internal to Cohen's contribution, or so I will argue. In the next section I will examine Cohen's understanding of the role of egalitarianism in a socialist society, but also bring out the ambiguity. In the 
final section I will attempt to resolve that ambiguity by arguing for the superiority of the life-sufficiency principle of distribution implied in Marx, Engels, and I will show, Cohen as well.

\section{II: Cohen: Egalitarianism and Socialism}

Cohen knows the core texts of Marxism as well as anyone and so he is aware of the arguments that Marx levelled against egalitarianism. Nevertheless, Cohen persists in reading even the principle of fully developed socialism (communism) as an egalitarian principle. "The achievement of Marxist equality (from each according to his abilities, to each according to his needs) is premised on a conviction that industrial progress brings society to a condition of such fluent abundance that it is possible to supply what everyone needs for a richly fulfilling life" (Cohen, 1995, 10) Why does Cohen regard this as an egalitarian principle, when, at least on the surface, Marx and Engels did not. Cohen regards it as an egalitarian principle because, viewed from the standpoint not of what each consumes and utilises (which will differ) but what each is able to achieve, the principle valorises equal outcomes for all. In other words, the equality at work in Marx's aphorism is general equality of condition leading to general equality of outcome and achievement: each is furnished with the resources each requires for the equally free development of their capacities. All are thus equally free to contribute to the social whole in the way each sees fit:

An overflowing abundance renders it unnecessary to press the talent of the naturally better endowed into the service of the poorly endowed for the sake of establishing equality of condition and it is therefore unnecessary to trench against or modify self-ownership, in order to achieve that equality. (Cohen, 1995, 122)

Cohen's subsequent development of his own conception of equality results from his claims that the historical, social, and political conditions have changed so drastically that no one can any longer plausibly believe that a society that satisfies the conditions laid down in Marx's aphorism is possible. Cohen's more nuanced views on the role of equality in socialism emerge out of his re-assessment of political possibility. I will explicate that reassessment and then move on to unpack more carefully Cohen's later views on equality in general and socialist equality in particular.

Cohen, as I noted, reads Marx's aphorism as an egalitarian principle which is no longer of live practical value, because the assumptions upon which it rests, both technological and political, have been falsified. He argues that the predictions that Marx made about universal working class solidarity have been shown false and that his 
assumptions about the power of technology to overcome natural scarcity have been refuted by the growing intensity of environmental crisis:

We cannot share Marx's optimism about material possibility, but we therefore also cannot share his pessimism about social possibility, if we wish to retain a socialist commitment. We cannot rely on technology to fix things for us: if they can be fixed, we have to fix them, through hard theoretical and political labour. (Cohen, 1995, 11)

In Cohen's view, Marx's social pessimism lay in his assumption that only absolute abundance could overcome the tendencies towards selfishness and conflict. Since the twentieth century has awoken to the ecological limits to absolute material abundance, this assumption of Marx's must be dropped.

Once socialists drop the utopian hope for absolute equality of freedom to pursue life-projects, they must confront a set of hard political and philosophical problems that the absolute abundance assumption allowed them to avoid. "We have to seek equality for a context of scarcity, and we consequently have to be far more clear ... about what we are seeking, and how it can be implemented, institutionally" Cohen, 1995, 10-11). These arguments are found in the egalitarian liberal tradition, with which socialists must now come to terms, and from which they must learn. "An attempt to pursue a consistent egalitarianism in political philosophy will be found within the literature of contemporary liberalism, which Marxists must, accordingly, address"(Cohen, 1995, 160). It was as a result of this conclusion that he began to take the "equality of what" debate seriously, as a potential source for a realistic principle of socialist organization.

Cohen's first major contribution to this debate was the paper "On the Currency of Egalitarian Justice." Cohen develops his position through critical engagement with the arguments of Rawls, Sen, Dworkin, and Arneson. My interests here are confined to Cohen's own answer and its relevance to the general problem at issue: is equality the normative foundation of socialism? In general, Cohen concludes, a just society must ensure what he calls "equal access to advantage." The key contribution to the debate, as Cohen sees it, made by his argument is to make clear the importance of the distinction "between choice and luck in shaping peoples fates" (Cohen, 1989, 907). Where inequalities arise from real choices that people make and can be held accountable for, there is no moral problem. Where inequalities result from bad luck-for example, the class into which one has been born-there is a social responsibility to correct for these disadvantages. "The right reading of egalitarianism," Cohen argues, is the one whose "purpose is to eliminate involuntary disadvantage, by which I (stipulatively) mean disadvantage for which the sufferer cannot be held responsible, since it does not appropriately reflect choices that he has made or is making or would make."(Cohen, 1989, 916). Cohen regards equal access to advantage as a more demanding form of 
equality than equality of primary goods (Rawls), capabilities (Sen), resources (Dworkin), or welfare (Arneson).

Cohen's entry into the 'equality of what debate' enabled him to pose and answer questions more or less foreign to the Marxist tradition: what role do tastes play in the production of inequalities, do inequalities that result from expensive tastes involve questions of justice, what is the difference between luck and choice, and, most generally and most importantly, what are the social conditions of responsibility for one's choices? Cohen does not directly consider the more particular question of what the significance of these arguments are for the understanding of the problem of the normative foundations of socialism (which remains in the background here even though that is the problem that motivated his turn towards the liberal debate). Nevertheless, its significance for addressing that problem is clear: if it is the case that socialists can no longer reasonably expect technological developments to simultaneously produce universal revolutionary consciousness and the material conditions that ensure a successful revolution, then they need a new idea of equality as their guiding norm. The idea of equality which is both appropriate to conditions of scarcity and best preserves the socialist project to which Cohen always remained committed is his conception of equal access to advantage, as the most thoroughgoing material equality of any of the alternatives on offer in the equality of what debate.

The connection between Cohen's intervention in the liberal equality of what debate and his abiding socialist commitments is made more clear in his systematic critique of Rawls in Rescuing Justice and Equality. The relevance of his argument for present purposes concerns the way in which Cohen exposes and calls into question the justice of the idea-which Rawls shares with neo-classical economics-that inequality is essential as motivation for those with capital to invest it in ways that better satisfy the interests of the worst off than available alternatives. "The persuasive power of this defence of inequality," Cohen contends, "has helped to drive authentic egalitarianism, of an old-fashioned, uncompromising kind, out of contemporary political philosophy. The present essay is part of an attempt to bring it back in" (Cohen, 2008, 87). Cohen thus remains a critic of the capitalist assumptions underlying Rawls argument without having to fall back on the utopian assumptions of classical Marxism whose intrinsic problems led him into the equality of what debate in the first place.

However, Cohen's defence of "old-fashioned" egalitarianism in Rescuing Justice and Equality does not include a systematic explication of what a contemporary socialist alternative would require. Rather, its significance for a socialist alternative is primarily negative, in that it exposes the way in which traditional capitalist incentive structures are assumed by Rawls, even though he claims to be neutral with regard to the choice between capitalism and socialism (Cohen, 2008, p. 163). In order to understand the positive significance that equality has for socialism we must turn to a short text which turned out 
to be Cohen's final contribution to the problem of the normative foundation of socialism: Why Not Socialism?

In Why Not Socialism? Cohen defends the desirability of socialism by employing an extended metaphor, a camping trip taken by a group of friends, in which each contributes in their own way to the satisfaction of the needs of the others and in turn is enabled to pursue those pursuits that most interest them. Some cook, some clean, some fish, some hike. In other words, in return for a contribution to the satisfaction of others needs, each is able to pursue their own goals-from each according to their abilities, to each according to their needs. The camping trip exemplifies, according to Cohen, "the socialist way, with collective property and planned mutual giving."(Cohen, 2009, 10) He then further explicates the "socialist way" by articulating the two normative principles upon which it rests: a socialist equality principle and a principle of community.

The socialist equality principle is distinguished from both classical liberal equality and left-liberal equality in so far as it corrects for disadvantages "that arise out of native differences as a further source of injustice, beyond that imposed by unchosen social backgrounds" Cohen, 2009, 17). Moreover, socialist equality of opportunity depends upon addressing the underlying structural causes of inequality of opportunity under capitalism: "Importantly, the removal of blocks to the opportunity of some people does not always leave the opportunities of the initially better placed intact ... I underline this point because it means that promoting equality of opportunity is not only an equalizing, but also a redistributing policy" (Cohen, 2009, 14) This last point makes Cohen's general egalitarian theory of equality of access to advantage politically concrete. One might thus think of the socialist principle of equality of opportunity as a species of the genus equality of access to advantage. It is what results when the general egalitarian principle is applied under conditions of class inequality, as the justification for the changes to the distribution of resources that capitalist class structure causes.

I agree-as any socialist would-that capitalism is marked by structural inequalities in "access to advantage." These structural inequalities appear as radically unequal opportunities for life-experience and enjoyment of the people who inhabit opposite ends of the income scale. Socialism of any sort must therefore be concerned with and propose realizable means of addressing these inequalities. At the same time, I do not believe that even this exigent form of equality is the normative foundation of socialism, and I believe that Cohen's second principle, the principle of community, points us in the direction of why it is not.

Like any principle of equality, the socialist principle of equality of opportunity depends upon interpersonal comparisons in its determination of what is an acceptable and what is an unacceptable form of inequality:

Preferences across income and leisure are not in principle different from preferences across apples and oranges, and there can be no objection to 
differences in people's benefits and burdens that reflect nothing but different preferences, when, (which is not always) their satisfaction leads to a comparable aggregate enjoyment of life (Cohen, 2009, 19).

The problem, from a socialist point of view, is that as a principle of equality, socialist equality of opportunity abstracts from the content of what counts as "enjoyment of life" for each and for all, and instead focuses on the problem of interpersonal comparisons relative to an abstract metric of equality. This comparison of concrete individuals according to an abstract standard is exactly that which caused Marx to reject equality as the normative foundation of socialism, because he always maintained, from his earliest philosophical work to his death, that socialism depended upon the ability of people to transcend the bourgeois perspective of invidious interpersonal comparison that any abstract metric of equality presupposes.

In Cohen's work this Marxist argument re-appears, although he does not see it as in tension with the socialist principle of equality. Nevertheless, if we think carefully about what his principle of community must presuppose about people and their relationships, a definite tension becomes evident. The principle of community maintains that "people care about, and, where necessary, care for, one another, and, too, care that they care about one another" Cohen, 2009, 34-35). Principles of equality-even the principle of socialist equality of opportunity-- do not presuppose that people care that they care about one another, only that they have the same amount of something as everyone else according to whichever metric of equality is being employed. Assuming equality, they could, without violating the spirit or the letter of the principle, care nothing further about each other. But such indifference would contradict the principle of community, and make socialism as a systematic alternative to capitalism impossible.

Cohen explicitly links acceptance of the principle of community to a rejection of the forms of social relationship that define capitalist market society. The principle of community "is the anti-market principle according to which I serve you not because of what I can get in return by doing so, but because you need ... my service, and you, for the same reason, serve me" Cohen, 2009, 39). In other words, the principle of community starts from the assumption that human beings are interdependent and cannot flourish as individuals save through cooperation and sharing of resources for the sake of ensuring our natural and social life-requirements are met. This assumption is distinct from the assumption of socialist equality, because, again, equality is a comparative term. It does not specify that which human beings require as natural and social beings in order to develop their capacities freely, nor does it establish any criteria or limits to the content of the capacities developed. But the principle of community, as his explication above implies, does: my capacities are to be realized in ways that satisfy others' needs in a virtuous circle of mutual self-development. 
The virtuous circle of need-satisfaction and capacity realization contrasts systematically with the principles of capitalist society.

Within market society ... the choices of others massively confine each individual's pursuit of her own choices, but that fact is masked in market society, because, unlike what is true on the camping trip, in market society the unavoidable mutual dependence of human beings is not brought into consciousness, as a datum for formal and informal planning (Cohen, 2009, 48).

It is essential to note that the object of formal and informal planning is not who gets how much of what in comparison with others, but with whether what each does contributes to the satisfaction of the needs of all the others. In other words, the raison d'etre of planning is to ensure that everyone's life-horizons are as wide as possible, by ensuring that the social forces generated by 'private' market decisions are constrained, not, in the first instance, by considerations of equality, but by considerations of shared need, of community, of care for the well-being of each and all.

\section{III: Socialism, Life-Coherence, and Life-Sufficiency}

Thus, the key tension in Cohen's work is between a principle of equality that relies on interpersonal comparisons and abstracts from the content of what people actually require and do, and a principle of equality which looks beyond interpersonal contrast to new relations of recognized interdependence and mutual need. What Cohen does not tell us is what in fact our fundamental needs are. In this silence he follows Marx, who, despite invoking the concept of need throughout his career never anywhere rigorously distinguishes it from the consumer demands his critique of capitalism ought to have led him to distinguish them from. In fact, in crucial places Marx out and out conflates needs with consumer demands, as when he argues, in "Wages, Price, and Profit," that a person remains content with a modest house that satisfies her need for shelter until her neighbour builds a "palace." The person in the modest dwelling then feels compelled to "need" a bigger house (Marx, 1973, 163; Noonan, 2006, 123). What the person feels, however, is not a fundamental need, if we define needs as objective and universal liferequirements, and objective and universal life-requirements as those resources, practices, relationships, and institutions which, if we are deprived of them, cause demonstrable harm to our lives and life-capacities (McMurtry, 1998, 164). The link between needs and capacities established in Marx's principle of fully developed socialism implies such a universal and objective definition of needs as life-requirements, but it is nowhere spelled out. 
Cohen also does not spell out any rigorous distinction between needs as liferequirements and consumer desires-between the resources etc., that human beings require to live and freely flourish and the things etc., that capitalist consumer markets require us to purchase if it is to accumulate capital. Yet, the definition proposed here is not completely foreign to Cohen's work, but implied in his prescient ecological arguments against the implications for the natural worlds of the unlimited abundance Marx imagined fully developed socialism to entail:

the development of the productive forces runs up against a resource barrier. Technical knowledge has not stopped, and will not stop growing, but productive power, which is the capacity (all things considered) to transform nature into use-value, cannot expand pari passu with the growth of technical knowledge, because the planet earth rebels: its resources turn out not to be lavish enough for continuous growth" (Cohen, 1995, 7).

Thus socialism requires not unlimited abundance, but economic development governed by the principle of life-coherence, and not equal levels of consumption at ever higher levels, but consumption limited by the principle of life-sufficiency.

The principle of life-coherence is implied by Cohen's ecological critique of the utopian demand for unlimited growth. Against the demand for unlimited growth the principle of life-coherence claims that only such patterns of economic development and social appropriation of resources is materially rational that "consistently enables ecological and human life together" (McMurtry, 2011, 14). This contrasts both with the capitalist system-requirement for endless economic growth, which Cohen, as a socialist, opposes, and Marx's blind faith in the powers of productive force development, which Cohen, as a self-critical socialist, also opposes. The principled basis of that opposition is not fully explicated in Cohen's work. Nevertheless, the life-coherence principle clearly satisfies that which is implied but unstated: the idea that economic growth must be lifeserving in order to be good, and it can only be human life-serving if it is does not destroy the natural basis of all life on earth. Social institutions and individual choices are thus life-coherent when they preserve and improve the life-enabling and life-developing powers of natural and social fields of life and life- incoherent when they degrade the former or employ the later to serve the particular interests of a definite social group against the shared life-interests of all, including the privileged group.

The principle of life-coherence exposes another hidden danger of making equality the normative principle of socialism. Equality can be achieved by raising up or lowering down, but in either case the term 'equality' itself can tell us nothing about whether production and distribution is either life-coherent or life-incoherent. That is, there is no contradiction, from the standpoint of any principle of equality, in socio-economic systems which strive for social equality at such a level of material abundance that 
impossible strains are placed on the natural environment. In order to see this problem the goal of equality must itself be grounded in the principle of life-coherence, for only if we view human society in the context of the global field of life-support do the limits to material abundance become clear. Once we begin to think of consumption not in capitalist terms, as an instrumental requirement of endless money-value growth, but in terms of what is actually required for a happy and fulfilling life, the problems of equality and inequality take on a different appearance, nicely captured by David Schweickart's question: "Would we be concerned about inequality if everyone in our society had enough?" (Schweikhart, 2011, 94). My response is that no, we would not be (or, we would not any longer be ethically obligated to be concerned about it). Thus, if we rethink the goal of equality in a life-coherent way, we are led, I suggest, to a reformulation of the fundamental goal of socialism: not equality of opportunity in the abstract, but lifesufficient provision of that which is universally required in order for each to live as a happy, engaged, fully contributing social self-conscious agent to the communal whole. This claim raises the obvious question of what exactly is required if that goal is to be realized for each and all.

I have defended a tripartite set of fundamental human life-requirements in other works over the past five years (Noonan, 2008, 118-37; Noonan, 2008a, 31-55, Noonan, 2009, 377-393, Noonan, 2011, 117-134, Noonan, 2012, forthcoming.). These sets of liferequirements comprise the physical-organic requirements of biological life (including food, water, shelter, clothing, and health care), the socio-cultural requirements of human life as a social self-conscious agent, (including familial love and care, education, access to natural beauty and artistic creation, a sustainable economy which produces life-valuable goods and enables all which require meaningful and non-alienated work to find it, and democratic participation across major social institutions) and the temporal requirements of free human activity, (comprised of an experience of time as an open matrix of possibilities for action and requiring for its realization the release of as much life-time as possible from the demands of coercive external routines). The satisfaction of these liferequirements is not intrinsically but instrumentally valuable as the natural and social conditions for the free development of those sentient, cognitive, imaginative, and creative capacities that distinguish human life and make it good and worth living. These liferequirements are to be distinguished from both consumer demands (whose satisfaction has no life-value) and instrumental conditions for the successful realization of any project whatsoever. While the instrumental conditions for the successful realization of any projects are needs relative to that project, only those projects which have instrumental or intrinsic life-value deserve social support. Projects that are manifestly life-destructive have no legitimate claim on natural or social wealth. The principle of life-sufficiency does not mandate that everyone receive an equal share of each life-requirement satisfiers or equal resources to pursue their life-valuable projects, but sufficient life-requirement satisfiers to ensure their life and free agency, subject to the principle of life-coherence as 
stated above. It is life-sufficient provision that can ensure the full developing everyone's social self-conscious agency in ways that contribute, as Cohen's principle of community demands, to the satisfaction of others' life-requirements and thus the development of their social self-conscious agency.

The principle of life-sufficient production and distribution thus implies intrinsic limits on the demands people make on natural and social resources. That does not mean that it mandates an ascetic life-style or subordinates individual happiness to reified conditions of environmental health. "Sufficiency" means sufficiency not just for mere biological life but human life, life as a socially self-conscious creative agent who is able and who enjoys contributing to the preservation of the natural system of life-support and the socio-cultural system of life-development. It re-grounds happiness from the illusory and all-too-ephemeral pleasures of the shopping mall to the activity of living as a unique, individual, creative member of complex communities. This form of life is, I believe, exactly the form of life that is demanded by Cohen's principle of community. Both envisage socialist society as a virtuous circle in which individuals' find meaning in their life as creative agents realizing their capacities in ways which serve the life-requirements of their fellow citizens, and are served in turn by them. There are innumerable particular ways in which this vocation can be lived: growing the food we need, building and fixing things our lives require, teaching, healing, caring for, cleaning, cooking, and reflecting upon and improving the existing ways of accomplishing these essential tasks. This virtuous circle is made the principle of social reality to the extent that social wealth is liberated from its form as private money-capital to become collectively controlled resources used to fund the institutions and practices that our lives as socially selfconscious agents require. Productivity gains, instead of being realized as higher profits and higher unemployment, are realized as more socially available time for free exploration and activity.

The principle of life-sufficiency is normatively more basic than even socialist equality of opportunity, since equality, socialist or otherwise, implies no intrinsic limits on that which people may demand, because equality is relative to an abstract metric, and it makes no demands on others or oneself, beyond holding oneself to levels of demand that do not exceed the abstract metric. "Life-sufficiency," by contrast, is objectively determinable by that which is required for life as a socially self-conscious contributing agent-water, not pop, attractive, well-made, and climate appropriate clothing for all, not haute couture for the few, love, care and friendship, not domination, instrumentalization, and violence, education and creativity, not the vapid distractions of capitalist consumer culture, and the experience of time as an open matrix of possibilities for action, not the external burdens of imposed routines devoid of intrinsically interesting activity. The contributions that each life makes to the creation of such a world are thus both intrinsically valuable, as the enjoyed expression of one's own capacities and talents, and 
instrumentally valuable, as real contributions to the conditions of other people's good lives.

If we think the principle life-coherence and the principle of life-sufficiency together we arrive at what I regard as the deepest normative foundation for socialism. This foundation can be expressed in a revised version of Marx's famous aphorism: "from each according to his or her capacities to make life-valuable contributions to nature, society and others' individual lives, to each according to his or her real life-requirements for the sake of his or her own self-development." This fundamental principle is implied by Cohen's principle of community, because it is a principle that demands that individual action proceed from knowledge of mutual interdependence, not as a negative limit on what one can do as an individual, but as a positive enabling condition and the raison d'etre of good action.

\section{References}

Arneson, Richard. (1989). "Equality and Equality of Opportunity for Welfare." Philosophical Studies, Vol. 55, pp. 106-139.

Cohen, G.A. (1989). “On the Currency of Egalitarian Justice.” Ethics, Vol. 99, pp. 90644.

Cohen, G.A. (1995). Self-Ownership, Freedom, and Equality. Cambridge: Cambridge University Press.

Cohen, G.A. (2008). Rescuing Justice and Equality. Cambridge, MA: Harvard University Press.

Cohen, G.A. (2009). Why Not Socialism? Princeton NJ: Princeton University Press.

Dworkin, Ronald. (1981). "Equality of Resources." Philosophy and Public Affairs, Vol. 10, pp. 271-302.

Engels, Friedrich. (1959). Anti-Duhring. Moscow: Foreign Languages Publishing House.

Engels, Friedrich. (1973). "Principles of Communism (1847)." Karl Marx and Friedrich Engels: Selected Works, Volume One. Moscow: Progress Publishers.

Lebowitz, Michael. (2006). Build it Now! (New York: Monthly Review Press). 
Marx, Karl. (1973). "Wage Labour and Capital," Marx and Engels: Selected Works Volume 1. Moscow: Progress Publishers.

Marx, Karl. (1975). "Economic and Philosophical Manuscripts of 1844." Karl Marx and Friedrich Engels: Collected Works, Vol. 3. New York: International Publishers.

Marx, Karl. (1978). "Critique of the Gotha Programme." The Marx-Engels Reader. Robert C. Tucker, ed. New York: W.W. Norton.

Marx, Karl. (1986). Capital, Vol. 1. Moscow: Progress Publishers.

Marx, Karl, and Engels, Friedrich. (1986). The Communist Manifesto. Moscow: Progress Publishers.

McMurtry, John. (1998). Unequal Freedoms. Toronto: Garamond.

McMurtry, John. (2011). "Human Rights versus Corporate Rights: Understanding Life Value, the Civil Commons, and Social Justice." Studies in Social Justice, 5(1), 2011, pp. 11-62.

Nielsen, Kai. (1988). “On Marx Not Being an Egalitarian.” Studies in Soviet Thought, 35 (4), 1988, pp. 287-326.

Noonan, Jeff. (2008). "Normative Political Economy." Research Focus on Political Economy.

Walter Levin, ed., Schenectedy: Nova Science Publishers, 118-135.

Noonan, Jeff. (2008a). "Reconstructing the Normative Foundations of Socialism." Socialist Studies, 4(1), pp. 31-55.

Noonan, Jeff. (2009). "Free Time as a Condition of a Free Human Life." Contemporary Political Theory, Vol. 8, November, 2009, pp. 377-393.

Noonan, Jeff. (2011). "Use Value, Life Value and the Future of Socialism." Re-Thinking Marxism, 23 (1), pp. 117-134.

Noonan, Jeff. (2012, forthcoming). Materialist Ethics and Life-Value. Montreal: McGillQueen's University Press. 
Schweickart, David. (2011). After Capitalism. Second edition. Lanham: MA: Rowman and Littlefield.

Sen, Amartya. (1980). "Equality of What? The Tanner Lectures on Human Values. Scott McMurrin, ed. Cambridge: Cambridge University Press.

Wood, Alan. (1981). "Marx and Equality." Issues in Marxist Philosophy, Volume Four: Social and Political Philosophy. John Mepham and David Hillel-Rubin, eds. Sussex: Harvester Press. 